\title{
Mechanical properties of carbide-free lower bainite in complex-alloyed constructional steel: Effect of bainitizing treatment parameters
}

\author{
V. I. Zurnadzhy ${ }^{1}$, V. G. Efremenko ${ }^{*}$, I. Petryshynets ${ }^{2}$, K. Shimizu ${ }^{3}$, M. N. Brykov ${ }^{4}$, \\ I. V. Kushchenko ${ }^{1}$, V. V. Kudin ${ }^{4}$ \\ ${ }^{1}$ Pryazovskyi State Technical University, Mariupol, Ukraine \\ ${ }^{2}$ Institute of Materials Research, Slovak Academy of Sciences, Kosice, Slovak Republic \\ ${ }^{3}$ Muroran Institute of Technology, Muroran, Japan \\ 4 "Zaporizhzhia Polytechnic" National University, Zaporizhzhia, Ukraine
}

Received 10 December 2019, received in revised form 19 January 2020, accepted 21 January 2020

\begin{abstract}
Tensile/impact behaviour of lower bainite obtained in high-Si steel $55 \mathrm{Si} 3 \mathrm{Mn} 2 \mathrm{CrMoVNb}$ was studied using SEM, TEM, and XRD. Specimens were austenitized at $900{ }^{\circ} \mathrm{C}$ and isothermally treated at 250,270 , and $300^{\circ} \mathrm{C}$ with holding up to $600 \mathrm{~min}$. The heat treatment results in the formation of cementite-free lower bainite/retained austenite structure, where retained austenite was found as blocky "islands" and interlaths "films". The width of bainitic ferrite laths decreases from $170-240 \mu \mathrm{m}$ to $45-80 \mu \mathrm{m}$ with holding temperature decreasing. This results in increasing UTS (to $1700 \mathrm{MPa}$ ) and hardness (to $52 \mathrm{HRC}$ ). The optimal combination of mechanical properties (UTS 1397-1522 MPa, hardness 45-47 HRC, total elongation 18-21\%, U-notched impact toughness $105-139 \mathrm{~J} \mathrm{~cm}^{-2}$ ) refers to holding at $300{ }^{\circ} \mathrm{C}$ to be associated with higher amount of retained austenite (30-33\%). With prolonging the bainitizing duration the hardness and ductility decreases while impact toughness increases. Prolonged holding at $300{ }^{\circ} \mathrm{C}$ leads to a continuation of bainite transformation and precipitation of transitional carbides within ferrite laths.
\end{abstract}

Key words: carbide-free lower bainite, retained austenite, phase transformations, microstructure, mechanical properties

\section{Introduction}

Currently, various heat treatment technologies are actively used to improve mechanical properties and exploitation durability of steel machine parts. One of the most effective approaches is the isothermal quenching (austempering) consisting in austenitization followed by the holding (bainitizing) at a temperature slightly higher than $M s$ point with eventual final cooling [1]. Isothermal quenching results in lower bainite structure, which provides an improved combination of strength, ductility, and impact toughness [2]. In addition, isothermal quenching leads to lower residual stresses with no distortion or cracking in the products, which is associated with temperature equalization in the products during the isothermal holding [3].
Beginning from the pioneering research of $\mathrm{H}$. Bhadeshia et al. in the 90 s and to the present, the approach to develop the high-strength steels with nanostructured carbide-free bainite (nanobainite) has been actively studied [4-6]. The main peculiarity of this structure is nanoscaled $(30-60 \mathrm{~nm}$ width) laths of bainitic ferrite with interlayers of carbon-enriched retained austenite (RA) with no cementite carbides $[7,8]$. Nanosized transition $\varepsilon$-carbide may precipitate within ferritic laths, providing additional strengthening effect $[9,10]$. The formation of carbide-free nanobainite is ensured by alloying with increased (1.53.0 wt.\%) amount of silicon or aluminium to suppress the cementite precipitation during bainite transformation $[5,11,12]$. Preventing cementite precipitation eventually results in austenite enrichment with

*Corresponding author: e-mail address: vgefremenko@gmail.com 
carbon leading to increase in RA volume fraction [13]. Nanoscaled ferritic laths impart higher strength (reaching 2000-2400 MPa), while the absence of cementite carbides and the presence of retained austenite films provide the increased ductility (elongation of $10 \%$ or higher) and impact toughness [5, 14, 15]. Moreover retained austenite may significantly contribute to mechanical properties due to TRIP-effect [16]. With that in mind, carbide-free lower bainite is considered as a desirable microstructural component of multiphase steels such as TRIP-aided steels [17] and Q\&P-treated (Quenching and Partitioning) steels [18, 19].

The $0.3-0.4$ wt.\% C steels with bainite were successfully used in the production of rails for particularly difficult operating conditions, such as heavily loaded curved sections of the railroad [20-22]. Nanobainite steels are known to be applied for the armours construction [23]. They are also considered as perspective materials with increased fatigue durability and wear resistance [24-27]. Improved wear behaviour of carbide-free lower bainite is associated with the transformation of retained austenite into martensite under wear, providing an increase in surface hardness [28] and stress relaxation [29]. The suitability of nanobainite steels as elements of welded constructions is investigated in [30] focusing on the properties in the heat-affected zone.

The production of nanobainite steels involves longlasting isothermal holding at a temperature below $250^{\circ} \mathrm{C}$ reaching up a week or more $[4,5,31]$ which is detractive for steels manufacturers. This refers to a very low rate of bainite transformation at temperatures below $M s$ point [32]. Attempts to accelerate the low-temperature transformation led to the development of nanobainitic steels alloyed with aluminium and cobalt [33]. Another approach is obtaining a certain fraction of athermal martensite in the structure that drastically reduces the incubation period of bainitic transformation [34]. The first approach increases the cost of steel, and the second one leads to reducing ductility because of the appearance of brittle martensite in the structure.

The alternative approach to nanobainite is lower carbide-free bainite obtained at the temperatures above $M s$ point; its formation does not involve too long isothermal holding [14]. Appropriate design of chemical composition could allow obtaining carbidefree lower bainite even at temperatures above $M s$ [12]. However, tensile/impact behaviour of this microstructure should be studied additionally to prove its competitiveness to nanobainite. Besides, the effect of prolonged isothermal holding (longer than it needs to complete bainite transformation) on mechanical properties of lower bainite has not been studied so well to choose the optimal duration of isothermal holding $[33]$. Based on above the object of this work was to evaluate the mechanical properties of newly designed $\mathrm{Ni}$-free steel $55 \mathrm{Si} 3 \mathrm{Mn} 2 \mathrm{CrMoVNb}$ after heat treatment for the structure of carbide-free lower bainite. The specific tasks of the research were: (a) to investigate the effect of bainitizing treatment parameters on tensile and impact behaviour of steel focusing on prolonged isothermal holding; (b) to explore the relationship "microstructure/mechanical properties" concerning lower bainite microstructure.

\section{Methods}

The study material was the steel $55 \mathrm{Si} 3 \mathrm{Mn} 2 \mathrm{CrMo}$ VNb containing: 0.56 wt.\% C; 2.50 wt.\% Si; 1.70 wt.\% $\mathrm{Mn} ; 0.50$ wt. $\%$ Cr; 0.21 wt. $\%$ Mo; 0.12 wt.\% V; 0.05 wt. $\% \mathrm{Nb} ; 0.006$ wt. $\% \mathrm{~S} ; 0.015$ wt.\% P. The chemical composition of steel was specifically designed to gain an advantageous $\mathrm{Q} \& \mathrm{P}$ treatment to form complex microstructure "martensite/carbide-free bainite/RA" [35]. The steel was smelted in laboratory induction furnace of $60-\mathrm{kg}$ capacity and rolled into a strip $15 \mathrm{~mm}$ thick, from which the specimens were manufactured for research. Heat treatment was fulfilled in an electric muffle furnace (austenitization) and in liquid 60 wt.\% Sn-40wt.\% Pb bath (bainitizing holding). The used modes of heat treatment are described in section 3.1 .

Optical mirror dilatometer was used to determine the steel critical temperatures $\left(A c_{1}, A c_{3}, M s\right)$ and the kinetics of austenite/bainite transformation. The specimen of $2 \mathrm{~mm}$ in diameter and $20 \mathrm{~mm}$ in length was used for the dilatometric study. The specimen was heated with the rate of $1 \mathrm{~K} \mathrm{~s}^{-1}$ to $900^{\circ} \mathrm{C}$ and then cooled at still air. The heating/cooling curves were recorded by light beam deflection fixed on the screen, located at a distance of $600 \mathrm{~mm}$ from the mirror. The critical points were found by the inflexion of heating/cooling curves connected with phase transformations. In the case of the kinetics of bainite transformation preliminarily austenitized at $900{ }^{\circ} \mathrm{C}$ specimen was transferred to bainitizing dilatometer furnace where it was held with dilatometric curve recording.

Tensile properties were determined by a tensile test using the samples of $5 \mathrm{~mm}$ diameter and $30 \mathrm{~mm}$ gauge. Impact toughness was measured by the Charpy test at room temperature using U-notched specimens of $7 \times 10 \times 55 \mathrm{~mm}^{3}$ size. Hardness was measured by Rockwell according to $\mathrm{C}$ scale. The microstructures and fracture surfaces were observed using Ultra-55 (Carl Zeiss) scanning electron microscope (SEM). The fine microstructure was examined using JEM-100-C-XII (JEOL) transmission electron microscope (TEM) at an accelerating voltage of $100 \mathrm{kV}$. The phase status of the steel was determined by the XRD method with diffractometer Pro-IV (Rigaku) in $\mathrm{CuK}_{\alpha}$ radiation. The volume fraction of retained austenite and 
carbon content in RA were calculated as described in $[36,37]$.

\section{Results}

\subsection{Critical points determination and transformation kinetics study}

The selection of the parameters of bainitizing treatment was preceded by a determination of the critical points $\left(A c_{1}, A c_{3}\right.$, and $\left.M s\right)$ and by studying the kinetics of austenite transformation in the bainite temperature range $\left(225-350^{\circ} \mathrm{C}\right)$. As follows from inflections on dilatometric heating/cooling curves (Fig. 1) the critical points of steel $55 \mathrm{Si} 3 \mathrm{Mn} 2 \mathrm{CrMoVNb}$ were determined as $800^{\circ} \mathrm{C}\left(A c_{1}\right), 840^{\circ} \mathrm{C}\left(A c_{3}\right)$, and $240{ }^{\circ} \mathrm{C}$ $(M s)$. Taking into account $A c_{3}$ position the temperature of austenitization before bainitizing holding was chosen as $900^{\circ} \mathrm{C}$ with holding of $10 \mathrm{~min}$.

Figure 2 depicts the kinetics of austenite transformation in steel $55 \mathrm{Si} 3 \mathrm{Mn} 2 \mathrm{CrMoVNb}$ at 250,270 , 300 , and $350{ }^{\circ} \mathrm{C}$ after austenitization at $900^{\circ} \mathrm{C}$. As follows from the analysis of kinetic curves (Fig. 2a), the minimum incubation period corresponds to $350^{\circ} \mathrm{C}$ $(55 \mathrm{~s})$. With holding temperature decrease the incubation period gradually increases to $420 \mathrm{~s}$ at $250^{\circ} \mathrm{C}$.

As seen, kinetics curves approach the horizontal line at different beam deflection. Beam deflection on dilatogram (dilatation effect) is influenced by different transformation features such as rate of $\gamma \mathrm{Fe} \rightarrow \alpha \mathrm{Fe}$ transition, carbon partitioning from bainitic ferrite (BF) to austenite, carbide precipitation, etc. Thus, light beam deflection is a superposition of mentioned factors; therefore, it does not directly correlate with the transformation rate only. The minimum beam deflection was noted for holding at $300^{\circ} \mathrm{C}$ which reflects a very low rate of transformation at this temperature. Supposedly, during holding at $300^{\circ} \mathrm{C}$, the transformation proceeded very slowly due to active enrichment of austenite by carbon leading to transformation suppressing on its earlier stage. The carbon enrichment at $300^{\circ} \mathrm{C}$ presumably was facilitated by higher carbon diffusivity and by presence of $2.5 \mathrm{wt} . \%$ Si which suppresses cementite precipitation from austenite [5]. Increasing holding temperature to $350^{\circ} \mathrm{C}$ stimulated the transformation due to an increase in carbon diffusion and cementite precipitation that resulted in higher transformation rate with much more significant dilatation effect. At $270^{\circ} \mathrm{C}$ the transformation developed more thoroughly as well in comparison with $300^{\circ} \mathrm{C}$ due to less austenite enrichment with carbon. Moreover, the dilatation effect at $270^{\circ} \mathrm{C}$ exceeds the one for $350^{\circ} \mathrm{C}$ that can be explained by increasing the carbon content in BF. According to previous research based on XRD study [11, 38, 39], the carbon content
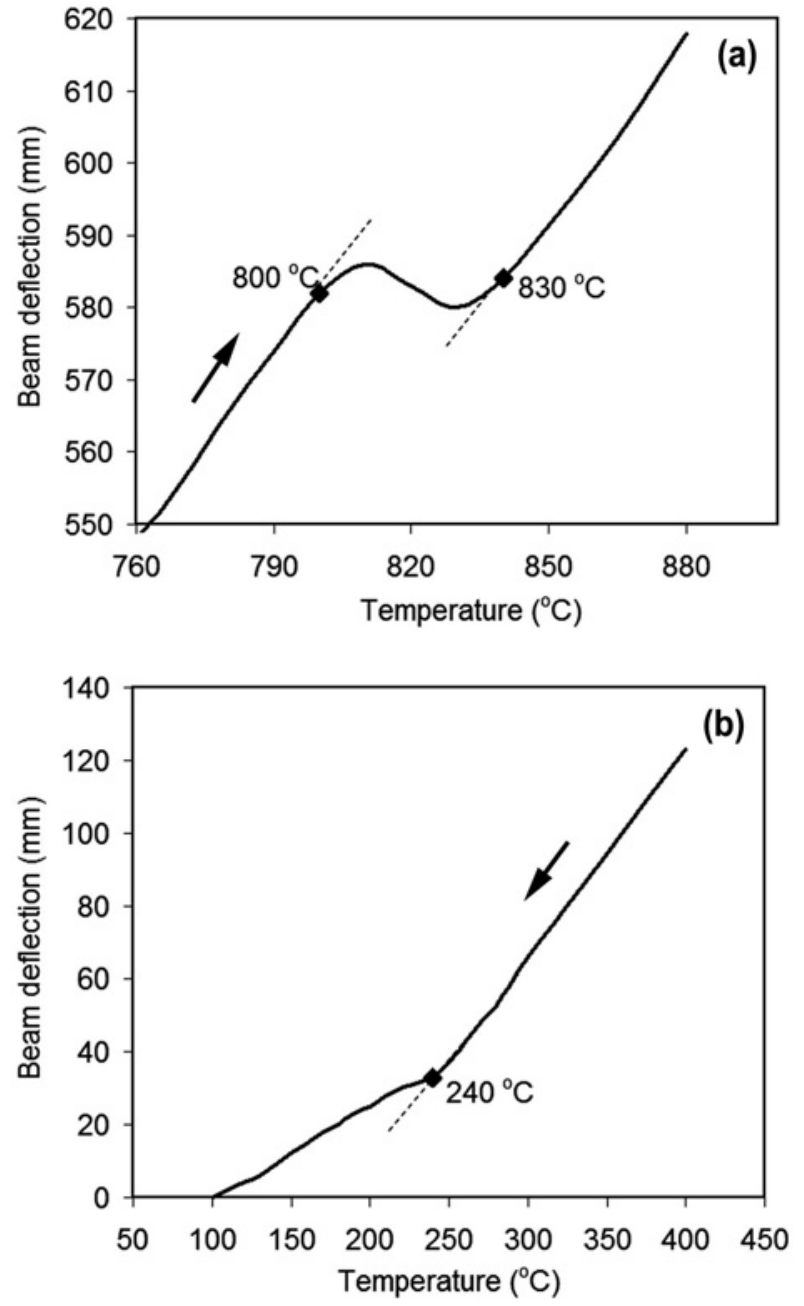

Fig. 1. Dilatometric curves for (a) heating and (b) cooling to determine critical temperatures of steel $55 \mathrm{Si} 3 \mathrm{Mn} 2 \mathrm{CrMo}$ $\mathrm{VNb}$.

in $\mathrm{BF}$ increases with transformation temperature decrease that results in increasing ferrite specific volume. This conclusion was confirmed lately by Rementeria et al. [40]. Using atom probe tomography, the authors [40] revealed in BF lath the carbon-clustered regions which are responsible for an increase in total tetragonality with transformation temperature decrease [41]. Isothermal holding at $250^{\circ} \mathrm{C}$ unexpectedly resulted in lower curve height as compared with $270^{\circ} \mathrm{C}$ despite lower content of retained austenite. This behaviour may occur because of lower transformation rate at $250{ }^{\circ} \mathrm{C}$ when the specimen extending (as a result of $\gamma \mathrm{Fe} \rightarrow \alpha \mathrm{Fe}$ phase transition) was partially compensated with specimen shortening due to carbon partitioning from $\mathrm{BF}$ to austenite and $\varepsilon$-carbide precipitation.

Using the data derived from kinetics curves, the bainite domain of TTT-diagram was constructed (Fig. 2b). Taking into account the data of critical points and transformation kinetics the parameters of 

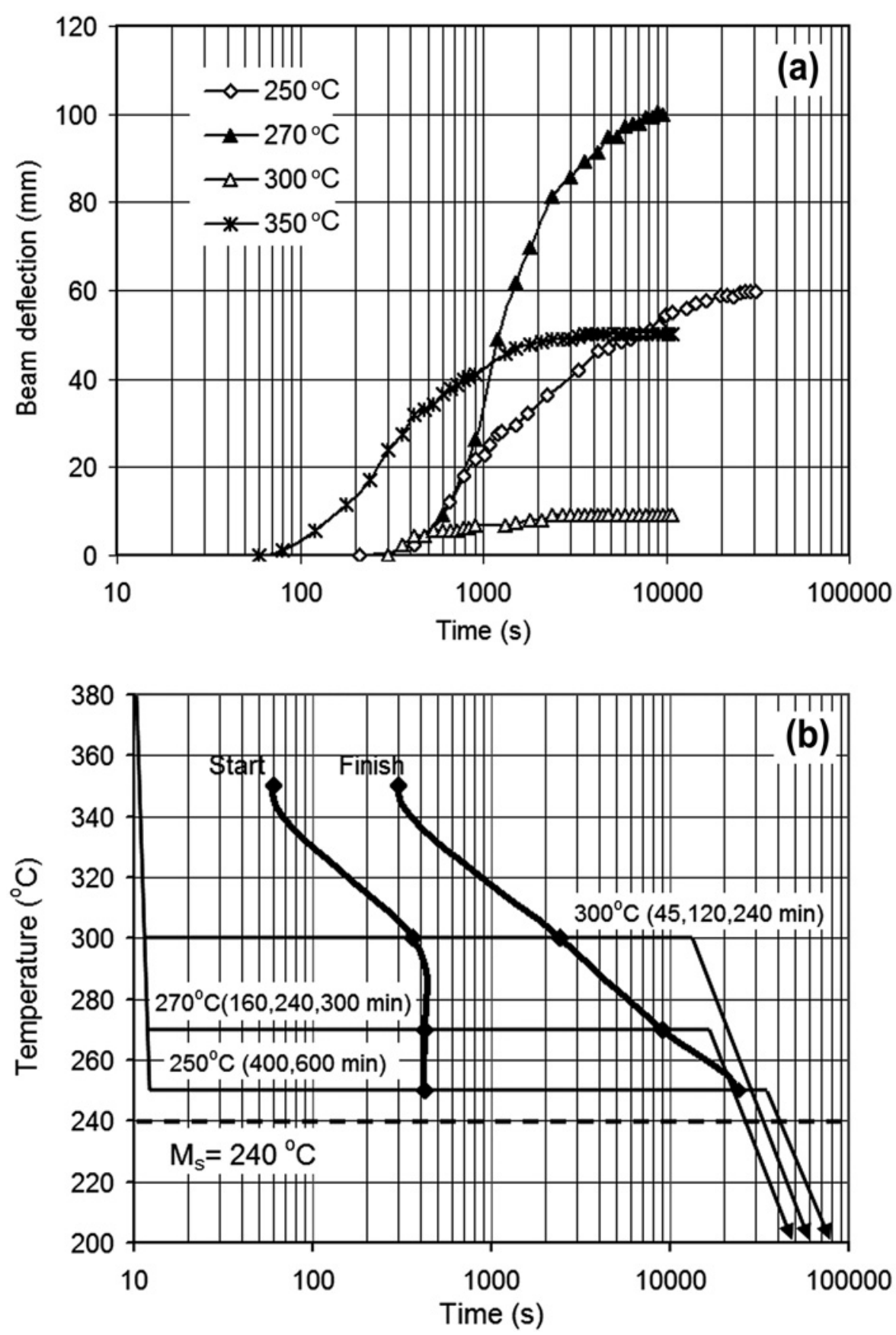

Fig. 2. (a) Kinetics curves of austenite transformation and (b) TTT-diagram of steel 55Si3Mn2CrMoVNb with schedules of bainitizing heat treatment used in work.

bainitizing heat treatment were determined as graphically shown in Fig. 2b. The specimens were austenitized at $900^{\circ} \mathrm{C}$ for $10 \mathrm{~min}$ with further fast transfer to liquid $\mathrm{Sn}-\mathrm{Pb}$ bath for isothermal holding at temperatures slightly above the $M s$ point which are specifically 300,270 , and $250^{\circ} \mathrm{C}$. Holding duration varied in the range of $45-600 \mathrm{~min}$ in order to: (a) reach the moment of bainite transformation accomplishment according to TTT-diagram (which are $45 \mathrm{~min}$ for $300^{\circ} \mathrm{C}, 160 \mathrm{~min}$ for $270^{\circ} \mathrm{C}, 400 \mathrm{~min}$ for $250^{\circ} \mathrm{C}$ ) and (b) study the effect of further prolonged hold- ing on bainite's mechanical properties. After holding completion, the specimens were cooled in calm air.

\subsection{Mechanical properties evaluation}

Table 1 presents the mechanical properties of studied steel after bainitizing heat treatment. As seen, the treatment resulted in high strength (UTS: 1397-1733 MPa, YTS: 1162-1496 MPa) while ductility retained at an increased level (Total Elongation 
Table 1. Mechanical properties of steel 55Si3Mn2CrMoVNb after bainitizing treatment

\begin{tabular}{|c|c|c|c|c|c|c|}
\hline \multirow{2}{*}{ Heat treatment } & YTS & UTS & \multirow{2}{*}{$\frac{\mathrm{TEL}}{(\%)}$} & \multirow{2}{*}{$\frac{\mathrm{PSE}}{(\mathrm{GPa} \%)}$} & \multirow{2}{*}{ Hardness, HRC } & \multirow{2}{*}{$\frac{\mathrm{KCU}}{\left(\mathrm{J} \mathrm{cm}^{-2}\right)}$} \\
\hline & \multicolumn{2}{|c|}{$(\mathrm{MPa})$} & & & & \\
\hline $300^{\circ} \mathrm{C}(45 \mathrm{~min})$ & 1210 & 1522 & 18 & 27.5 & 47 & 105 \\
\hline $300^{\circ} \mathrm{C}(120 \mathrm{~min})$ & 1162 & 1397 & 21 & 28.8 & 45 & 116 \\
\hline $300^{\circ} \mathrm{C}(240 \mathrm{~min})$ & 1171 & 1397 & 12 & 16.9 & 43 & 139 \\
\hline $270^{\circ} \mathrm{C}(160 \mathrm{~min})$ & 1353 & 1585 & 10 & 15.1 & 50 & 126 \\
\hline $270^{\circ} \mathrm{C}(240 \mathrm{~min})$ & 1337 & 1542 & 12 & 18.4 & 49 & 133 \\
\hline $270^{\circ} \mathrm{C}(300 \mathrm{~min})$ & 1447 & 1604 & 11 & 17.5 & 49 & 136 \\
\hline $250^{\circ} \mathrm{C}(400 \mathrm{~min})$ & 1456 & 1697 & 12 & 20.9 & 52 & 107 \\
\hline $250^{\circ} \mathrm{C}(600 \mathrm{~min})$ & 1438 & 1733 & 10 & 17.0 & 48 & 114 \\
\hline
\end{tabular}
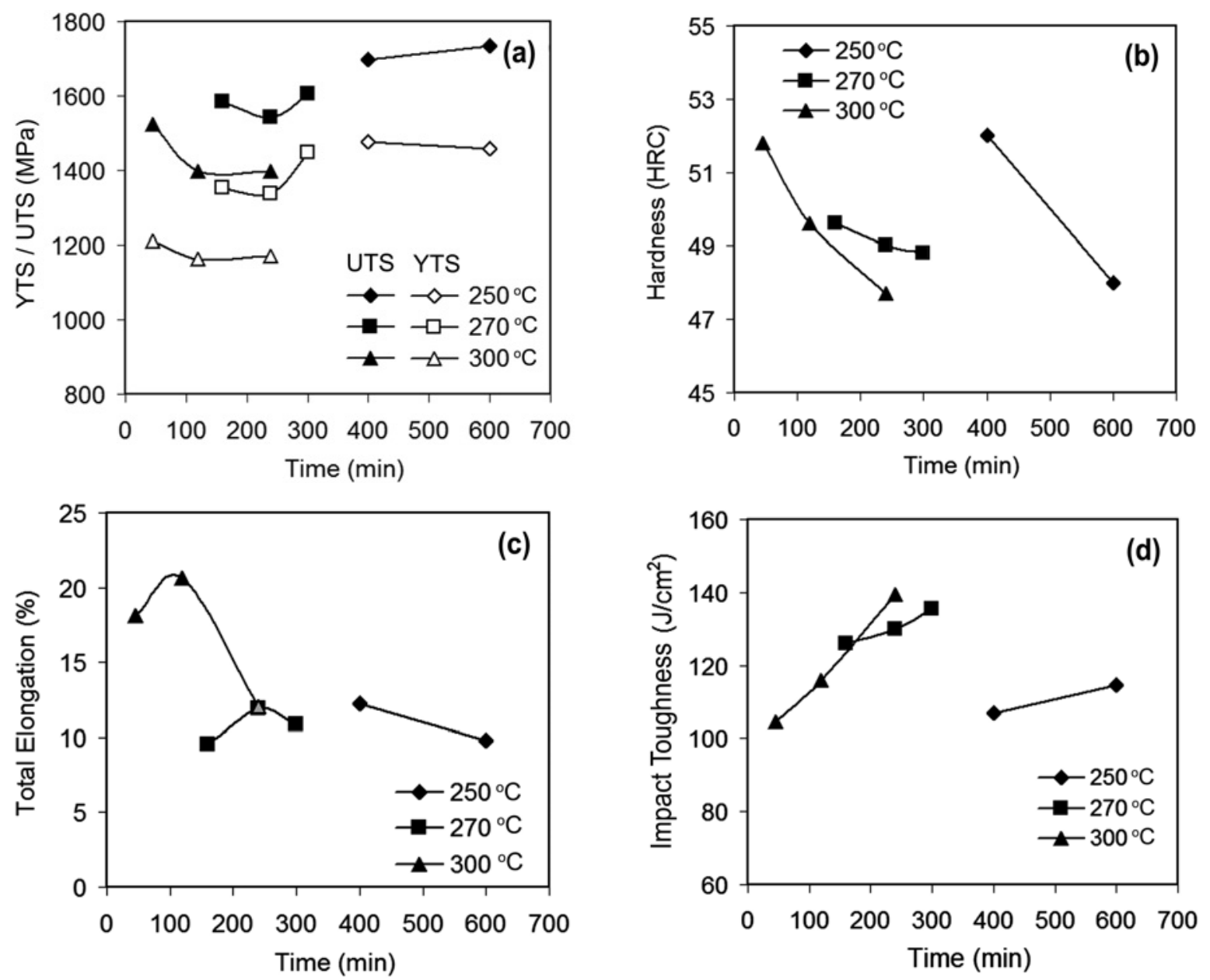

Fig. 3. Effect of holding duration at different bainitizing temperature on mechanical properties of steel 55Si3Mn2CrMoVNb.

(TEL): 10-21\%). PSE index (Product of Strength and Elongation) varied from 15.1 to $28.8 \mathrm{GPa} \%$. The impact toughness values were in the range of $105-139 \mathrm{~J} \mathrm{~cm}^{-2}$. These data reveal that middle carbon steel $55 \mathrm{Si} 3 \mathrm{Mn} 2 \mathrm{CrMoVNb}$ acquired an advanced "strength/ductility/impact toughness" combination wherein its ductility/toughness level is rather characteristic for low-carbon steels.

The maximum strength (UTS $1733 \mathrm{MPa}$, YTS
$1697 \mathrm{MPa}$ ) was achieved after bainitizing at $250^{\circ} \mathrm{C}$ for $600 \mathrm{~min}$. With such strength, steel performed acceptable ductility (TEL 10\%) and higher impact toughness (KCU $114 \mathrm{~J} \mathrm{~cm}^{-2}$ ). The optimal complex of mechanical properties was ensured by holding at $300^{\circ} \mathrm{C}$ for 45-120 min. In this case, the steel possessed a tensile strength of $1397-1522 \mathrm{MPa}$ and hardness of 45-47 HRC with total elongation of 18-21\%. Notably, impact toughness values were $105-139 \mathrm{~J} \mathrm{~cm}^{-2}$ while 
PSE index reached its maximum values (27.5-28.8 $\mathrm{GPa} \%$ ).

The effect of bainitizing parameters on the mechanical properties of steel is shown graphically in Fig. 3 . There is pronounced trend of increasing of strength and hardness as the holding temperature decreases (Fig. 3a). Conversely, ductility and impact toughness tend to decrease with bainitizing temperature decrease (Figs. 3b,e).

As seen in Fig. 3a, holding duration slightly decreases UTS at $300^{\circ} \mathrm{C}$ while it has no significant effect on UTS at 270 and $250^{\circ} \mathrm{C}$. In contrast, hardness dropped with holding duration at any bainitizing temperature (Fig. 3d). Holding at $250^{\circ} \mathrm{C}$ for $400 \mathrm{~min}$ gives the maximum hardness ( $52 \mathrm{HRC}$ ) though it tends to decrease to $48 \mathrm{HRC}$ after prolonged holding (600 min). The minimum hardness value (43 HRC) corresponds to bainitizing at $300^{\circ} \mathrm{C}$ for $240 \mathrm{~min}$.

For ductility other trend was observed. The holdings at 270 and $250^{\circ} \mathrm{C}$ provided no effect on TEL, resulting in approximately the same total elongation (10-12\%). In contrast, at $300^{\circ} \mathrm{C}$ TEL varied by the curve with maximum corresponded to $120 \mathrm{~min}$ (Fig. 3b).

Impact toughness increases monotonically with increasing holding duration at all temperatures. This trend is more pronounced at $300^{\circ} \mathrm{C}$, and to a lesser extent, at $250^{\circ} \mathrm{C}$ (Fig. 3e). Analyzing the data shown in Fig. 3e, it should be noted that for each bainitizing temperature impact toughness reaches a rather high level (over $100 \mathrm{~J} \mathrm{~cm}^{-2}$ ), which is usually observed in steels alloyed with $2-4$ wt.\% $\mathrm{Ni}$ [42]. Holding at 270 $300^{\circ} \mathrm{C}$ ensures a higher level of impact toughness compared with holding at $250^{\circ} \mathrm{C}$.

\subsection{Microstructure and fracture surface characterization}

The microstructure of bainitized steel is presented in Fig. 4. The characteristic feature of all heat treatment regimes is a fine grain (number 10-10.5) due to alloying by strong carbide-forming elements (V, $\mathrm{Nb}$ ). As seen in Fig. $4 \mathrm{a}$, bainitizing at $300^{\circ} \mathrm{C}$ results in a structure consisting of packages of ferritic $\alpha$ phase laths with retained austenite areas distributed throughout the structure. The decrease in bainitizing temperature to $250^{\circ} \mathrm{C}$ led to decrease in the bainitic laths width and RA volume fraction, which is in agreement with the data presented in $[4,5]$ (Fig. 4c).

The features of the fine structure of lower bainite were revealed using transmission electron microscopy (Fig. 5). The lower bainite is composed of the packets consisting of parallel $\alpha$-phase laths divided by filmlike retained austenite; blocky "islands" of austenite are also observed at the junction of the packets (Fig. 5a,b). The presence of austenite films is confirmed by dark-field observation in the austenite re-
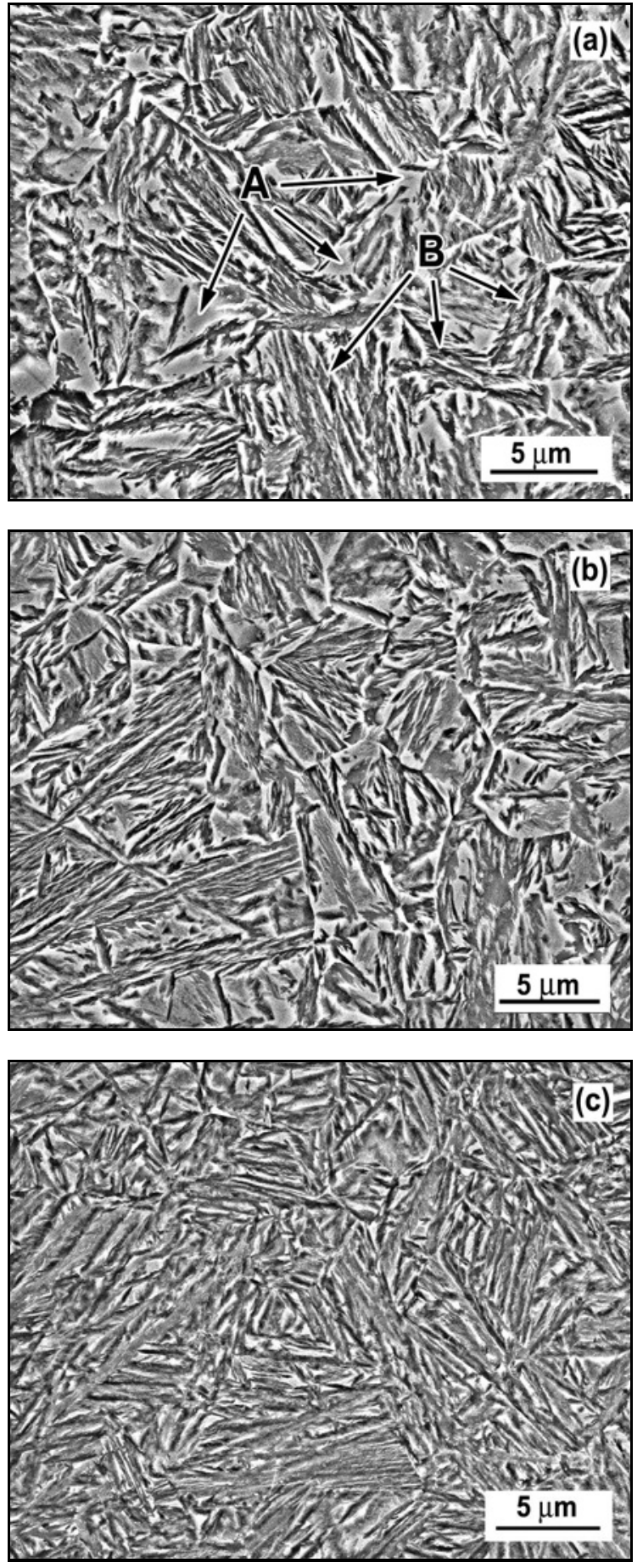

Fig. 4. Microstructure (SEM) of steel $55 \mathrm{Si} 3 \mathrm{Mn} 2 \mathrm{CrMoVNb}$ after holding at (a) $300{ }^{\circ} \mathrm{C}$ for $240 \mathrm{~min}$, (b) $270{ }^{\circ} \mathrm{C}$ for $300 \mathrm{~min}$, (c) $250^{\circ} \mathrm{C}$ for $400 \mathrm{~min}$ (A, B - austenite, bainite, accordingly).

flection (Fig. 5c). The thickness of the bainitic $\alpha$ phase laths decreases from $170-240 \mathrm{~nm}$ at $300^{\circ} \mathrm{C}$ to $45-80 \mathrm{~nm}$ at $250^{\circ} \mathrm{C}$; thus, at the latter case, bainite is nanostructured. The $\alpha$-phase laths have a higher density of dislocation, induced by accommodative mi- 

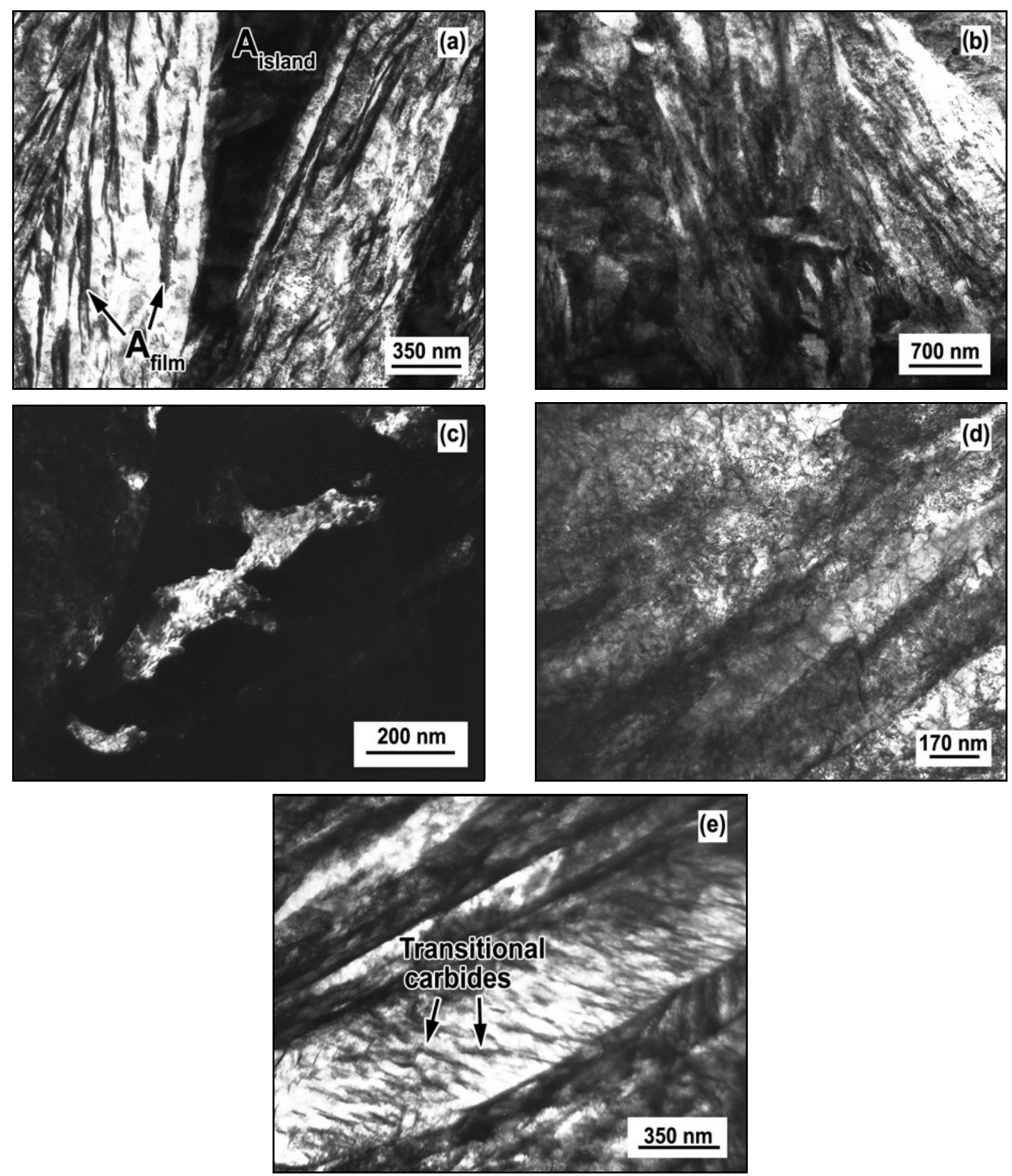

Fig. 5. TEM microstructure of steel $55 \mathrm{Si} 3 \mathrm{Mn} 2 \mathrm{CrMoVNb}$ after holding at (a) $250{ }^{\circ} \mathrm{C}$ for $400 \mathrm{~min}$ and (b-e) $300{ }^{\circ} \mathrm{C}$ for $240 \mathrm{~min}$; (a, b) bainitic $\alpha$-phase laths with "film" and blocky "island" of retained austenite; (c) dark-field image of austenite reflection from the axis of the $[111] \gamma$ zone; (d) dislocation structure of $\alpha$-phase laths; (e) transitional carbides inside $\alpha$-phase lath (A - retained austenite).

croplastic deformation during displacive $\gamma \rightarrow \alpha$ transformation (Fig. 5d). The analysis of TEM images and diffraction patterns revealed no presence of cementite carbide, which confirms the carbide-free nature of obtained lower bainite. Instead, the transitional $(\varepsilon)$ carbides were revealed to be precipitated within ferrite laths (Fig. 5e).
Evaluation of the phase status of bainitized steel was performed using XRD analysis (Fig. 6). Diffraction peaks related to $\alpha$-Fe $((110) \alpha,(200) \alpha,(211) \alpha$, $(220) \alpha)$ and to austenite $((111) \gamma,(200) \gamma,(220) \gamma$, $(311) \gamma$ ) were revealed in all XRD patterns. It was found that the integral intensity of the austenite peaks increases with holding temperature increase. The vol- 


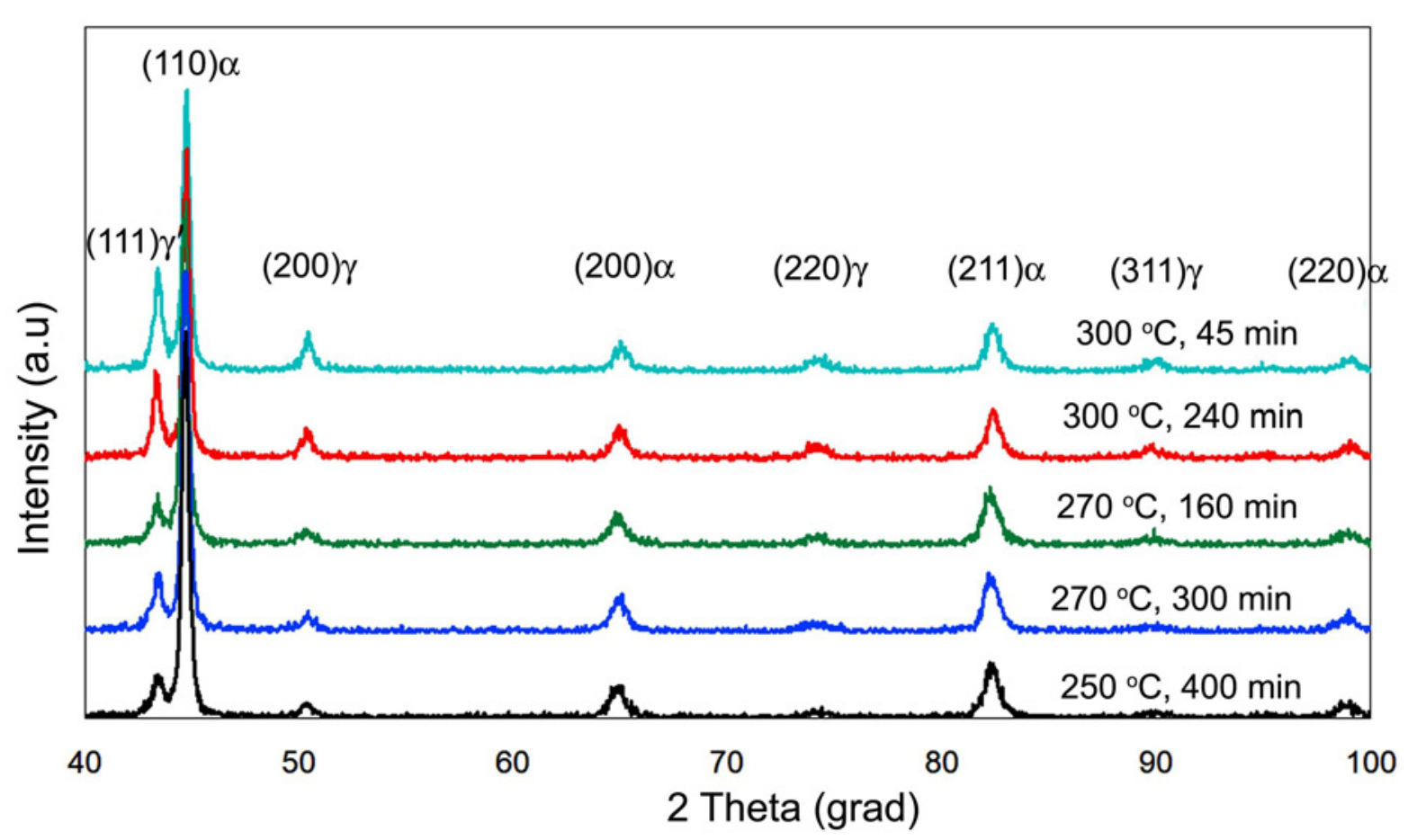

Fig. 6. XRD patterns of heat-treated specimens.
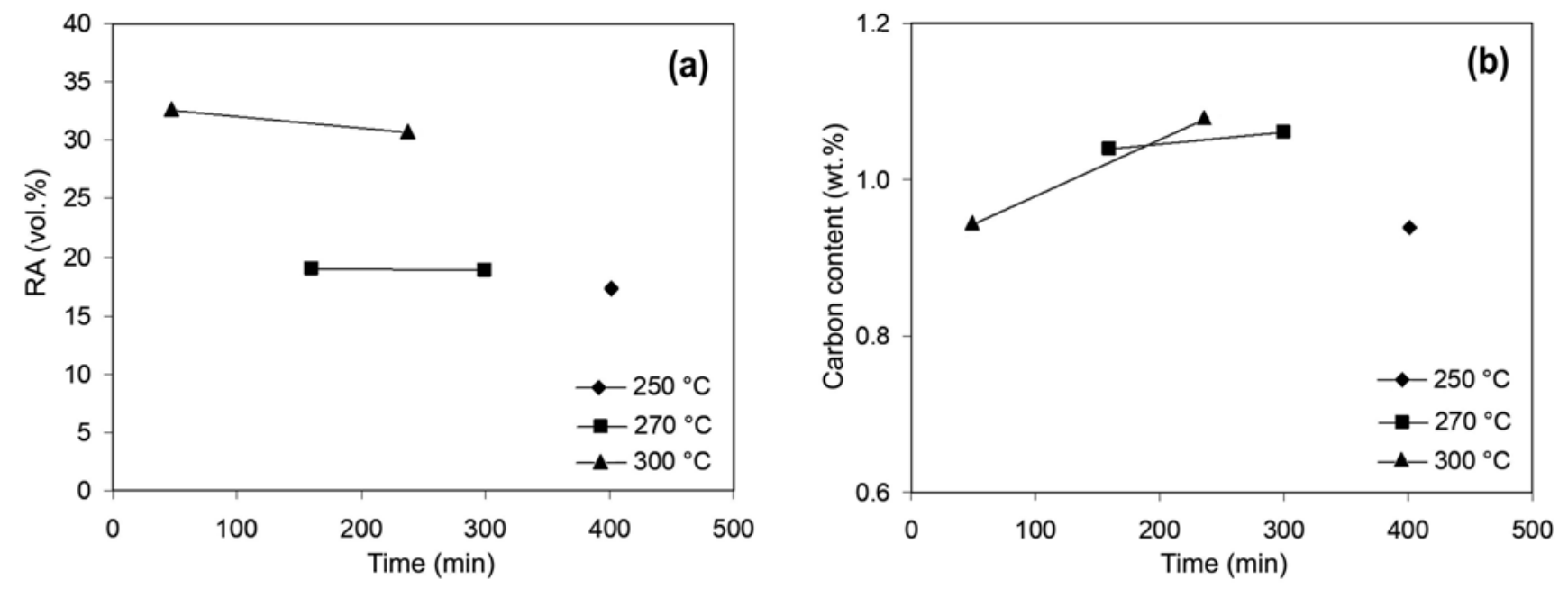

Fig. 7. The effect of holding duration on (a) RA volume fraction and (b) carbon content in RA.

ume fraction of retained austenite and carbon content in RA are presented in Fig. 7 as a function of holding duration. The highest RA volume fraction (32.6 vol.\%) was measured for holding at $300^{\circ} \mathrm{C}$ for $45 \mathrm{~min}$, while the carbon concentration in austenite was $0.94 \mathrm{wt} . \%$, which is almost two-fold of the average carbon content in the steel. With an increase in holding duration to $240 \mathrm{~min}$, the RA volume fraction slightly decreases to 30.6 vol.\% with an increase in carbon concentration to 1.08 wt.\%. After holding at 270 and $250^{\circ} \mathrm{C}$, RA volume fractions are much less to be $18-19$ vol. $\%$ and 18.1 vol.\% accordingly, while the carbon concen- tration in RA reaches about 1.05 and 0.94 vol.\%, respectively. At these temperatures the effect of holding duration on $\mathrm{RA}$ volume fraction/C content is not so pronounced as for $300^{\circ} \mathrm{C}$. XRD data are in accordance with the above finding of sharp suppression of bainite transformation at $300^{\circ} \mathrm{C}$ (Fig. 2a) because of strong chemical stabilization of austenite (with $\mathrm{C}$ ) resulting in increased RA volume fraction.

The question arises if some of alpha-phase is fresh martensite formed under the final cooling after isothermal holding. This martensite obviously may form from austenite remaining to the end of holding. It 

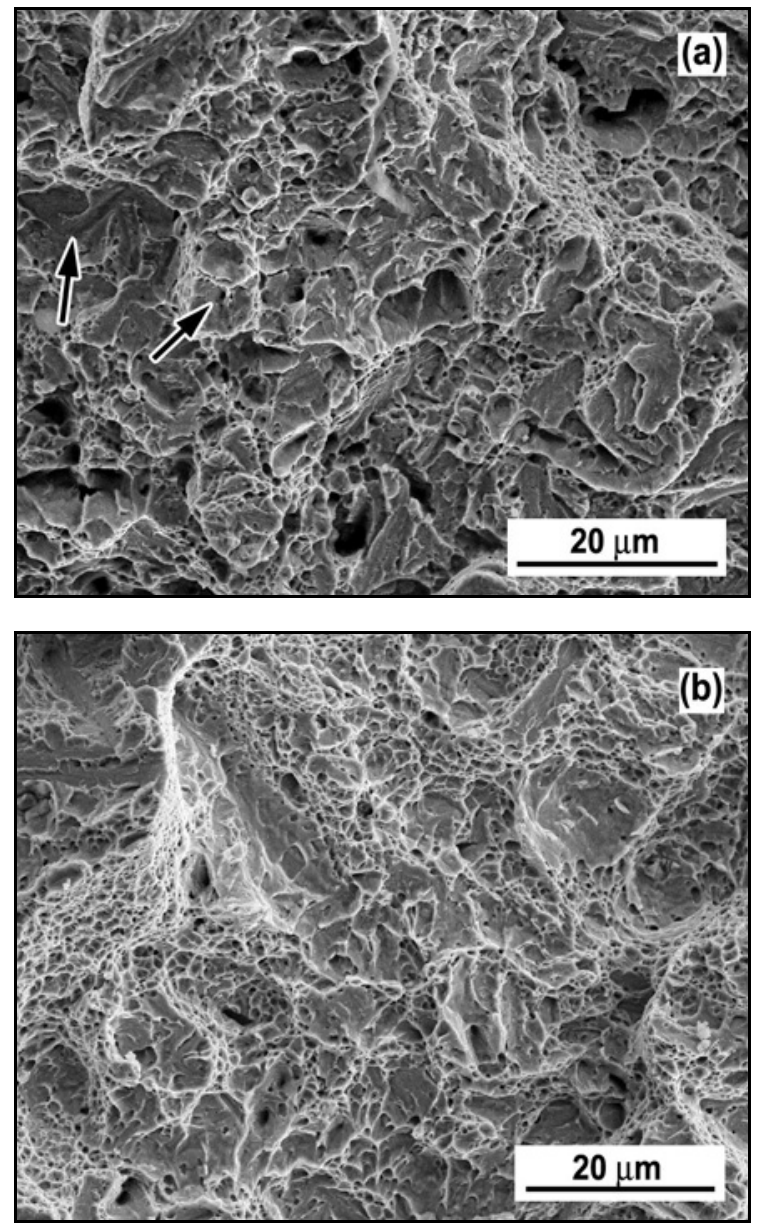

Fig. 8. Fractured surface of the specimens after impact loading. Bainitizing at $300^{\circ} \mathrm{C}$ for (a) $45 \mathrm{~min}$ and (b) $240 \mathrm{~min}$.

depends on $M s$ temperature, which can be calculated by using the empirical equation [38]:

$$
\begin{gathered}
M s\left({ }^{\circ} \mathrm{C}\right)=525-350(\mathrm{C}-0.05)-45 \mathrm{Mn}-35 \mathrm{~V}-30 \mathrm{Cr}- \\
20 \mathrm{Ni}-16 \mathrm{Mo}-5 \mathrm{Si}-16 \mathrm{Al}+6 \mathrm{Co},
\end{gathered}
$$

where the symbols present the concentration of the elements (wt.\%).

Assuming that carbon content in retained austenite is $0.94-1.08$ wt.\% (as revealed from XRD measurements) and taking the elements ( $\mathrm{Si}, \mathrm{Mn}, \mathrm{Cr}, \mathrm{Mo})$ content in steel $55 \mathrm{Si} 3 \mathrm{Mn} 2 \mathrm{CrMoVNb}$ as austenite chemical composition, then calculated $M s$ temperature is 53-102 ${ }^{\circ} \mathrm{C}$. That means that fresh martensite may appear after isothermal holding at $250-300^{\circ} \mathrm{C}$, contributing to steel strength. However, its volume fraction should be negligible since $M s$ is close to room temperature. Furthermore, fresh martensite should appear within small austenite areas making its observation difficult even using TEM technique.

U-notched fractured specimens were characterized with SEM to reveal fracture behaviour of carbide-free lower bainite under impact loading. In general, all the specimens performed rather ductile rupture mechanism. Figure 8 depicts the fractured specimens bainitized at $300^{\circ} \mathrm{C}$. The specimen held for $45 \mathrm{~min}$ has the fractured surface consisting of trans-crystalline quasicleavage facets (shown by arrows), surrounded by areas of copious dimples (Fig. 8a). The characteristic brittle "river-like" pattern was not found. With the prolongation of holding to $240 \mathrm{~min}$ the area fraction of the ductile component (dimples) increases, which is consistent with the increase in impact toughness (Fig. 8b).

\section{Discussion}

As follows from Fig. 3, two main trends connected with bainitizing treatment regime were observed. The first is that the strength/hardness of lower bainite in steel $55 \mathrm{Si} 3 \mathrm{Mn} 2 \mathrm{CrMoVNb}$ is inversely proportional to holding temperature. Based on microstructural characterization this behaviour can be explained by a decrease in the thickness of bainitic ferrite plates $[4,5]$. Another probable reason is an increase in carbon content in bainitic $\alpha$-phase because of lower carbon diffusivity $[11,42]$.

The second trend is connected with an effect of prolonged holding on bainite's mechanical properties that is of great interest. As seen in Fig. 3, holding duration at 250 and $270^{\circ} \mathrm{C}$ very slightly affects strength and ductility. On the contrary, holding at $300^{\circ} \mathrm{C}$ leads to decrease in strength and to non-monotonous variation of TEL with a maximum at $120 \mathrm{~min}$. As to hardness and impact toughness, they were significantly influenced by holding duration at any bainitizing temperature. Specifically, hardness decreased and impact toughness rose with holding duration increase. The latter reached an excellent level $\left(>130 \mathrm{~J} \mathrm{~cm}^{-2}\right)$ which is beneficial for $\mathrm{Ni}$-free steel with increased strength/hardness.

As was proven by TEM and XRD study, trend mentioned above is caused by superposition of structural processes taking place under prolonged holding, namely: (a) precipitation of transitional carbide inside ferrite laths, (b) gradual prolongation of bainite transformation with eventual decrease in RA volume fraction, and (c) enrichment of retained austenite with carbon. Precipitation of $\varepsilon$-carbide led to a decrease in carbon content in ferrite resulting in a decrease in the micro distortion of its crystal lattice (i.e., softening effect). This consequently reduced the hardness while improved impact toughness due to promoting dislocation movement. Besides, copious $\varepsilon$-carbide precipitates inside bainitic ferrite acted as nuclei for dimples formation which ensured the ductile mechanism of impact fracture. 
Notably, the carbon content in RA at $300^{\circ} \mathrm{C}$ increased with holding duration increase (Fig. 7b). This can be considered as a proof of bainite transformation continuation under prolonged holding since the transformation is accompanied by carbon partitioning to austenite. The higher transformation rate the higher $\mathrm{C}$ content in remaining austenite that is promoted by suppression of cementite precipitation due to alloying with 2.5 wt. $\% \mathrm{Si}$.

It should be noted that prolongation of duration at $300^{\circ} \mathrm{C}$ to $240 \mathrm{~min}$ leads to decrease in ductility while impact toughness tends to be increased. This means that total elongation is more sensitive to RA volume fraction while impact toughness is somewhat influenced by the strength of ferritic laths. Thus, the decrease in retained austenite is detrimental for TEL while the softening of ferrite (due to $\varepsilon$-carbide precipitation) is beneficial for impact toughness.

The results obtained show that the structure of carbide-free lower bainite provides an advanced complex of strength, ductility, and impact toughness in medium-carbon $\mathrm{Ni}$-free steel (55Si3Mn2CrMoVNb), which makes it promising as high-strength material for use in various operating conditions combining static and dynamic loading. It is essential that this structure is obtained after significantly shorter holding as compared with nanobainitic steels thus providing lower production costs.

\section{Conclusions}

Based on the results obtained, the major conclusions were drawn from this research:

(a) Bainitizing at $250-300^{\circ} \mathrm{C}$ with holding up to $600 \mathrm{~min}$ results in formation in steel $55 \mathrm{Si} 3 \mathrm{Mn} 2 \mathrm{CrMo}$ $\mathrm{VNb}$ the microstructure of carbide-free lower bainite consisting of bainitic ferrite laths and retained austenite of blocky or interlath film morphologies. Cementite carbides were not detected in the structure; instead, transitional carbides precipitated within ferritic laths. Lower bainite obtained at $250^{\circ} \mathrm{C}$ is nanoscaled having ferrite laths of $45-80 \mathrm{~nm}$ width.

(b) Carbide-free lower bainite structure ensured an advanced complex of strength/ductility/impact toughness in steel $55 \mathrm{Si} 3 \mathrm{Mn} 2 \mathrm{CrMoVNb}$. The optimal properties combination (UTS $=1397-1522 \mathrm{MPa}$, TEL $=18-21 \%, \mathrm{KCU}_{20}=105-116 \mathrm{~J} \mathrm{~cm}^{-2}, \mathrm{PSE}=27.5$ $28.8 \mathrm{GPa} \%$ ) is achieved by holding at $300^{\circ} \mathrm{C}$ for 45-120 min. This combination refers to an increased amount of retained austenite (30-33\%), stabilized by carbon (up to 1.08 wt.\%) during bainitic transformation. The bainitized steel is fractured under impact loading by a predominantly ductile mechanism combining trans-crystalline quasi-cleavage facets and dimple relief.

(c) Prolonged holding at bainitizing temperature leads to a decrease in hardness and to increase in impact toughness as compared with the moment of transformation completion. Prolonged holding at $300^{\circ} \mathrm{C}$ results in the continuation of bainite transformation with correspondent enrichment of remaining austenite with carbon.

\section{Acknowledgements}

This work was financially supported by SAIA (Slovak Academic Information Agency).

\section{References}

[1] Z. Jiang, X. Liu, J. Han, Effect of austenitizing processes on isothermal quenching microstructure in bearing steel, Adv. Mater. Res. 887-888 (2014) 276-280. doi:10.4028/www.scientific.net/AMR.887-888.276

[2] Yu. N. Simonov, M. Yu. Simonov, D. O. Panov, V. P. Vylezhnev, A. Yu. Kaletin, Formation of structure of lower bainite due to isothermal treatment of steels of types Kh3G3MFS and KhN3MFS, Met. Sci. Heat Treat. 1-2 (2016) 61-70. doi:10.1007/s11041-016-9965-z

[3] G. E. Totten, M. Howes, T. Inoue (Eds.), Handbook of Residual Stress and Deformation of Steel, first ed., ASM International, Materials Park, 2002.

[4] F. G. Caballero, H. K. D. H. Bhadeshia, K. J. A. Mawella, D. G. Jones, P. Brown, Very strong low temperature bainite, Mater. Sci. Technol. 18 (2002) 279284. doi:10.1179/026708301225000725

[5] C. Garcia-Mateo, F. G. Caballero, T. Sourmail, M. Kuntz, J. Cornide, V. Smanio, R. Elvira, Tensile behaviour of a nanocrystalline bainitic steel containing 3 wt.\% silicon, Mater. Sci. Eng. A 549 (2012) 185-192. doi:10.1016/j.msea.2012.04.031

[6] F. Liu, G. Xu, Y. Zhang, H. Hu, L. Zhou, Z. Xue, In situ observations of austenite grain growth in FeC-Mn-Si super bainitic steel, Int. J. Miner. Metall. Mater. 20 (2013) 1060-1066. doi:10.1007/s12613-013-0834-0

[7] S. Sharma, S. Sangal, K. Mondial, Development of new high strength carbide-free bainite steels, Metall. Mater. Trans. A 42 (2011) 3921-3933. doi:10.1007/s11661-011-0797-6

[8] J. Zhao, T. S. Wang, B. Lv, F. C. Zhang, Microstructures and mechanical properties of a modified high-CCr bearing steel with nano-scaled bainite, Mater. Sci. Eng. A, 628 (2015) 327-331. doi:10.1016/j.msea.2014.12.121

[9] H. K. Sung, S. Y. Shin, B. Hwang, C. G. Lee, S. K. Lee, Effects of cooling conditions on microstructure, tensile properties, and Charpy impact toughness of lowcarbon high-strength bainitic steels, Metall. Mater. Trans. A 44 (2013) 294-302. doi:10.1007/s11661-012-1372-5

[10]. H. Y. Li, X. W. Lu, W. J. Li, X. J. Jin, Microstructure and mechanical properties of an ultrahigh-strength $40 \mathrm{SiMnNiCr}$ steel during the one-step quenching and partitioning process, Metall. and Mat. Trans. A 41 (2010) 1284-1300. doi:10.1007/s11661-010-0184-8 
[11] G. V. Kurdiumov, L. M. Utevskii, R. I. Entin, Transformations in Iron and Steel. Nauka, Moscow, 1977. (in Russian)

[12] Yu. N. Simonov, D. O. Panov, M. Yu. Simonov, V. P. Vylezhnev, A. S. Ivanov, Principles of design of the chemical composition of steels for forming a structure of lower carbide-free bainite under delayed cooling, Met. Sci. Heat Treat. 7-8 (2015) 386-394. doi:10.1007/s11041-015-9894-2

[13] J. G. Speer, D. K. Matlock, B. C. De Cooman, J. G. Schroth, Carbon partitioning into austenite after martensite transformation, Acta Mater. 51 (2003) 2611-2622. doi:10.1016/S1359-6454(03)00059-4

[14] D. O. Panov, Yu. N. Simonov, P. A. Leontev, A. Yu. Kaletin, M. N. Georgiev, Formation of structure and properties of carbide-free bainite in steel 30KhGSA, Met. Sci. Heat Treat. 1-2 (2016) 71-75. doi:10.1007/s11041-016-9966-y

[15] A. Karimi, S. Kheirandish, M. Mahmoudiniya, Effect of bainite volume fraction on mechanical properties of a ferrite-bainite-martensite steel, Kovove Mater. 55 (2017) 175-182. doi:10.4149/km_2017_3_175

[16] W. Bleck, X. Guo, Y. Ma, The TRIP Effect and its application in cold formable sheet steels, Steel Res. Int. 88 (2017) 1700218. doi:10.1002/srin.201700218

[17] H. N. El-Din, R. Reda, Retained austenite attributes and mechanical performance of different compositions of TRIP steel alloys, J. Mater. Eng. Perform. 28 (2019) 2167-2177. doi:10.1007/s11665-019-04010-5

[18] G. Gao, H. Zhang, Z. Tan, W. Liu, B. Bai, A carbidefree bainite/martensite/austenite triplex steel with enhanced mechanical properties treated by a novel quenching-partitioning-tempering process, Mater. Sci. Eng. A 559 (2013) 165-169. doi:10.1016/j.msea.2012.08.064

[19] V. G. Efremenko, V. I. Zurnadzhi, Y. G. Chabak, O. V. Tsvetkova, A. V. Dzherenova, Application of the Q-nP-treatment for increasing the wear resistance of low-alloy steel with $0.75 \%$ C, Material Science 53 (2017) 67-75. doi:10.1007/s11003-017-0045-3

[20] K. K. Wang, Z. L. Tan, G. H. Gao, X. L. Gui, R. D. K. Misra, B. Z. Bai, Ultrahigh strength/toughness combination in bainitic rail steel: the determining role of austenite stability during tempering, Mater. Sci. Eng. A 662 (2016) 162-168. doi:10.1016/j.msea.2016.03.043

[21] O. P. Ostash, V. V. Kulyk, V. D. Poznyakov, O. A. Haivorons'kyi, L. I. Markashova, V. V. Vira, Z. A. Duriagina, T. L. Tepla, Fatigue crack growth resistance of welded joints simulating the weld-repaired railway wheels metal, Arch. Mater. Sci. Eng. 86 (2017) 49-52. doi: 10.5604/01.3001.0010.4885

[22] U. P. Singh, B. Roy, S. Jha, S. K. Bhattacharyya, Microstructure and mechanical properties of as rolled high strength bainitic rail steels, Mater. Sci. Technol. 17 (2001) 33-38. doi:10.1179/026708301101509098

[23] W. Burian, J. Marcisz, B. Garbarz, L. Starczewski, Nanostructured bainite-austenite steel for armours construction, Arch. Metall. Mater. 59 (2014) 12111216. doi:10.2478/amm-2014-0210

[24] V. G. Efremenko, O. Hesse, Th. Friedrich, M. Kunert, M. N. Brykov, K. Shimizu, V. I. Zurnadzhy, P. Suchmann, Two-body abrasion resistance of high- -carbon high-silicon steel: Metastable austenite vs nanostructured bainite, Wear 418-419 (2019) 24-35. doi:10.1016/j.wear.2018.11.003

[25] O. Hesse, J. Liefeith, M. Kunert, A. Kapustyan, M. Brykov, V. Efremenko, Bainite in steels with high resistance to abrasive wear, Tribol. Schmierungstech. 63 (2015) 5-13. (in German)

[26] T. Sourmail, F. G. Caballero, C. Garcia-Mateo, V. Smanio, C. Ziegler, M. Kuntz, R. Elvira, A. Leiro, E. Vuorinen, T. Teeri, Evaluation of potential of high Si high C steel nanostructured bainite for wear and fatigue applications, Mater. Sci. Technol. 29 (2013) 1166-1173. doi:10.1179/1743284713Y.0000000242

[27] E. Balalayeva, V. Artiukh, V. Kukhar, O. Tuzenko, V. Glazko, A. Prysiazhnyi, V. Kankhva, Researching of the stress-strain state of the open-type press frame using elastic compensator of errors of "Press-Die" system, Proceedings of International Scientific Conference Energy Management of Municipal Transportation Facilities and Transport, EMMFT 2017. Advances in Intelligent Systems and Computing 692 (2018) 220-235. doi:10.1007/978-3-319-70987-1_24

[28] O. Hesse, J. Merker, M. Brykov, V. Efremenko, On the strength of low-alloy steels with increased carbon content against abrasive wear, Tribol. Schmierungstech. 60 (2013) 37-43. (in German)

[29] L. S. Malinov, V. L. Malinov, D. V. Burova, V. V. Anichenkov, Increasing the abrasive wear resistance of low-alloy steel by obtaining retained metastable austenite in the structure, Journal of Friction and Wear 36 (2015) 237-240. doi:10.3103/S1068366615030083

[30] K. Fang, J. G. Yang, L. Zhao De, K. J. Song, Z. J. Yan, H. Y. Fang, Review of nanobainite steel welding, Adv. Mater. Res. (Durnten-Zurich, Switz.) 482-484 (2012) 2405-2408. doi:10.4028/www.scientific.net/AMR.482-484.2405

[31] S. Khare, K. Lee, H. K. D. H. Bhadeshia, Carbide-free bainite: Compromise between rate of transformation and properties, Metall. Mater. Trans. A 41 (2010) 922928. doi:10.1007/s11661-009-0164-z

[32] A. Yu. Kaletin, Yu. V. Kaletina, Evolution of the structure and properties of silicon steels in the austenite-bainite phase transition, Phys. Solid State 57 (2015) 59-64. doi:10.1134/S106378341501014X

[33] B. Avishan, Effect of prolonged isothermal heat treatment on the mechanical behaviour of advanced NANOBAIN steel, Int. J. Miner. Metall. Mater. 24 (2017) 1010-1020. doi:10.1007/s12613-017-1490-6

[34] I. A. Yakubtsov, G. R. Purdy, Analyses of transformation kinetics of carbide-free bainite above and below the athermal martensite-start temperature, Metall. Mater. Trans. A 43 (2012) 437-446. doi:10.1007/s11661-011-0911-9

[35] W. Li, H. Gao, Z. Li, H. Nakashima, S. Hata, W. Tian, Effect of lower bainite/martensite/retained austenite triplex microstructure on the mechanical properties of a low-carbon steel with quenching and partitioning process, Int. J. Miner. Metall. Mater. 23 (2016) 303313. doi:10.1007/s12613-016-1239-7

[36] J. Sun, H. Yu, Microstructure development and mechanical properties of quenching and partitioning $(\mathrm{Q} \& \mathrm{P})$ steel and an incorporation of hot-dipping gal- 
vanization during Q\&P process, Mater. Sci. Eng. A 586 (2013) 100-107. doi:10.1016/i.msea.2013.08.021

[37] V. I. Zurnadzhy, V. G. Efremenko, K. M. Wu, A. Yu. Azarkhov, Yu. G. Chabak, V. L. Greshta, O. B. Isayev, M. V. Pomazkov, Effects of stress relief tempering on microstructure and tensile/impact behavior of quenched and partitioned commercial spring steel, Mater. Sci. Eng. A 745 (2019) 307-318. doi:10.1016/i.msea.2018.12.106

[38] M. K. Kang, Y. L. Ai, M.-X. Zhang, Y. Q. Yang, M. Zhu, Y. Chen, Carbon content of bainite ferrite in 40CrMnSiMoV steel, Mater. Chem. Phys. 118 (2009) 438-441. doi:10.1016/j.matchemphys.2009.08.014

[39] J. H. Jang, H. K. D. H. Bhadeshia, D.-W. Suh, Solubility of carbon in tetragonal ferrite in equilibrium with austenite, Scr. Mater. 68 (2013) 195-198. doi:10.1016/j.scriptamat.2012.10.017
[40] R. Rementeria, J. D. Poplawsky, M. M. Aranda, W. Guo, J. A. Jimenez, C. Garcia-Mateo, F. G. Caballero, Carbon concentration measurements by atom probe tomography in the ferritic phase of high-silicon steels, Acta Mater. 125 (2017) 359-368. doi:10.1016/j.actamat.2016.12.013

[41] R. F. Rosalia, J. D. Poplawsky, E. Garrote, R. Dominguez-Reyes, C. Garcia-Mateo, F. G. Caballero, Carbon supersaturation and clustering in bainitic ferrite at low temperature, Conference, 5th International Symposium on Steel Science (ISSS 2017), Kyoto, 2017, 29-34. https://www.osti.gov/servlets/purl/1474491

[42] L. N. Belyakov, A. F. Petrakov, N. G. Pokrovskaya, A. B. Shal'kevich, New high-strength steels, Met. Sci. Heat Treat. 39 (1998) 334-337.

doi:10.1007/BF02467631 